\title{
Introduction: The Atlantic Alliance at 70-insight and evaluation
}

\author{
John R. Deni ${ }^{1}$. Sten Rynning ${ }^{2}$
}

(C) The Editor of the Journal 2019

The Atlantic Alliance's 70th anniversary in April 2019 is an intriguing challenge to scholars of international security cooperation, political science, and history for several reasons. First, there is no comparable case of alliance longevity among sovereign countries. History tells us that most alliances break up after a few years or in any case following the demise of whatever threat begot the alliance in the first place. Second, several material and ideational factors compete to explain the Atlantic Alliance's duration, including the structure of the international system, the governing mechanisms of the alliance's member states, and the collective identity forged by shared values and common struggle against totalitarian enemies. Third, the alliance's policy scope has grown dramatically in the past two decades, encompassing an agenda far beyond the external threats that initially prompted Europeans and North Americans to commit to each other's defense.

For these reasons, NATO leaders were right to again declare their alliance strategically relevant as they commemorated the 70th anniversary. Whether this is the case is beyond debate-NATO remains the most powerful intergovernmental organization on the planet, clearly relevant in, and able to affect outcomes in Europe and well beyond. How the alliance strives to structure regional and world politics in an era characterized by increasing competition among great powers, continuing instability along Europe's periphery, and challenges to the status quo domestically on both sides of the Atlantic remains the key question facing not only policy-makers but the epistemic community as well.

In recent years, a relentless focus on burden-sharing issues on the part of US President Donald Trump has at times overshadowed discussions centered on shared threat perceptions, common strategies, and complementary policies, which demand

John R. Deni

john.r.deni.civ@mail.mil

Sten Rynning

sry@sam.sdu.dk

1 US Army War College, 47 Ashburn Drive, Carlisle, PA 17013, USA

2 Center for War Studies, University of Southern Denmark, Johannevej 3A, 5000 Odense C, Denmark 
considered attention and energy on the part of all heads of state and government. Even as agreement on many of these issues remains elusive, NATO continues to pursue security agendas that are both old-deterrence, defense, and strategic competition-and new_-global partnerships, crisis management, and non-state actors. This special issue will address NATO's continuing efforts to build, sustain, and defend the transatlantic community across both security studies agendas.

This special issue and the decision to examine NATO at 70 were born out of what amounted to a workshop during the annual convention of the International Studies Association (ISA) in San Francisco from April 4-7, 2018. We were grateful to the other authors for their participation in that event and for their broader efforts since then in building this special issue.

From a theoretical perspective, this special issue takes a problem-focused approach to inquiry, emphasizing understanding of the subject matter over hypothesis testing. To the extent the articles of the issue address theory, they primarily do so from the perspective of actor-specific theorizing, which is necessary given NATO's uniqueness and which must involve the crossing of established theoretical boundaries and the questioning of established perspectives.

The first article in this special issue-by co-editor Sten Rynning-sets the scene for these inquiries by examining the alliance as a forum for consultations on the broad array of challenges confronting the transatlantic community. Rynning finds that many European allies have become accustomed to an incremental Atlanticist approach that no longer serves them well, and he suggests how Europe can leap forward to revive the tradition of consultations.

The second article of the special issue-by co-editor John R. Deni-takes a broad look at how the alliance has managed to sustain itself for seven decades and how its member states continue to leverage it to fulfill their own often-diverging security interests. Deni argues that the degree to which NATO endures appears to be a function of the continued relevance of the classical security agenda of deterrence and defense and the concomitant importance of the new agenda-including crisis management, energy security, mil-to-mil cooperation, and other non-collective defense issues - that has blossomed since the early 1990s. The paradox, posits Deni, is that it remains increasingly difficult for NATO to achieve its objectives in both spheres.

From these broad perspectives, the special issue will move on to an array of specific topics confronting NATO today but which resonate across the alliance's 70 years. For instance, Jeffrey Larsen addresses the essence of the old agenda, namely nuclear deterrence and strategy. Larsen argues that for most of the post-Cold War era, NATO has downplayed the role of nuclear weapons. This increased cohesion among the allies, especially so for those that have long been politically uncomfortable with nuclear deterrence. That comfort level is now under siege though, thanks in part to Russian military doctrine on the early use of nuclear weapons as well as budding capabilities of states such as Iran and North Korea. Larsen argues that this is exposing fault lines within the alliance, making it difficult for NATO to maintain consensus.

The fourth article, by Anna Wieslander, examines how formerly neutral Sweden and Finland shape and are shaped by collective defense thinking in NATO in ways that hitherto had been unimaginable. Wieslander argues that these two 
countries have emerged as 'informal allies'-states that are as close to the alliance as any can get without formally joining NATO and hence being 'covered' by Article 5's mutual defense clause. She examines in detail how these vitally important relationships, unique to NATO's post-Crimea approach to partners, impact alliance decision making, operational planning, and crisis response.

After looking north, the special issue turns south, as Antonio Marquina examines the alliance's approach to the Mediterranean over the last several decades. Marquina outlines the many initiatives launched since 1994, drawing particular attention to the lack of conceptual consistency. In his view, this is part of a broader lack of NATO strategy toward the southern flank, despite recent attempts to design consistent policies in a new regional environment. Marquina finds that NATO's efforts to project stability without an overarching strategy weaken and necessarily limit the reach of the practical initiatives.

Looking even farther afield, the sixth article by Stephan Fruehling examines global partners and NATO's ability to structure its diplomatic relations for impact on the international order. As part of its cooperative security mission, NATO essentially redefined its role in the post-9/11 world. NATO's relevance for its Asia-Pacific partners in fact long predates this period. Today, during a time of renewed great power competition, NATO and US allies in Asia should look to their shared interests, values, and need for functional coordination as the main benefits of their partnership. In this respect, Fruehling argues the North Atlantic Council should be further developed as a forum for political-strategic consultations between European and Asian allies.

Finally, James Goldgeier offers a capstone article that reflects on the alliance at 70 not simply through the lens of turbulent times but also in the broader context of the transatlantic bargain, especially from Washington's perspective. In particular, Goldgeier examines two trends that cast doubt on the robustness of US support for NATO. One is President Donald Trump's assault on the post-World War II order by championing hyper-nationalism and economic protectionism. The other is the deepening partisan divide emerging in US public opinion data on favorable views of NATO shaped by presidential rhetoric.

In sum, this special issue of the Journal of Transatlantic Studies delivers a cutting-edge assessment of NATO's cohesion and strategic potential. More broadly, this special issue provides policy-makers, the epistemic community, and informed readers a high-quality examination of the durable alliance in an era of dramatically shifting great power relations and domestic political change. We hope you find this special issue compelling, insightful, and thought-provoking.

Publisher's Note Springer Nature remains neutral with regard to jurisdictional claims in published maps and institutional affiliations.

John R. Deni is a research professor of Joint, Interagency, Intergovernmental, and Multinational (JIIM) Security Studies at the US Army War College's (USAWC) Strategic Studies Institute (SSI). He is also an adjunct lecturer at the American University's School of International Service. Previously, he worked for 8 years as a political advisor to senior US military commanders in Europe. Dr. Deni has spoken at 
conferences and symposia throughout Europe and North America, and he is the author, editor, or coeditor of seven books, including NATO and Article 5: The Transatlantic Alliance and the Twenty-FirstCentury Challenges of Collective Defense.

Sten Rynning is professor of international relations at the Department of Political Science, University of Southern Denmark where he also heads the Center for War Studies. Sten Rynning was on the advisory panel to the Danish war commission covering Kosovo, Afghanistan, and Iraq (2017-2019), a member of the official Norwegian Afghanistan Commission (2015-2016), and on the advisory panel to Ambassador Peter Taksøe-Jensen's official review of Danish Foreign Policy (2015-2016). He sits on the advisory board of the Danish Defence College and the editorial board of the European Journal of International Security, International Affairs, the Journal of Strategic Studies, and the Scandinavian Journal of Military Studies. He was a visiting fellow at NATO's Defence College, Rome, in 2012, and president of the Nordic International Studies Association, 2011-2015, and scholar in residence at American University's School of International Service (2017). Sten Rynning is the author of numerous books and articles, including NATO in Afghanistan: The Liberal Disconnect (Stanford University Press 2012), co-author (with Theo Farrell and Terry Terriff) of Transforming Military Power since the Cold War: Britain, France, and the United States, 1991-2012 (Cambridge University Press 2013), and 'The divide: France, Germany and political NATO,' International Affairs (93/2, 2017, 267-289). 